\title{
"We feed the world": the political ecology of the Corn Belt's driving narrative
}

\author{
Andrea Rissing ${ }^{1}$ \\ Ohio State University, USA
}

\begin{abstract}
Industrial grain production occupies most of Iowa's farmland. Around the edges of corn and soybean monocultures, however, small-scale, diversified farmers establish alternative agricultural operations and sell to local markets. One narrative, "we feed the world", stretches across these two spheres; its roots lie in postWorld War II geopolitics, and its contemporary iterations reflect the actions of private agricultural interest groups. As a rhetorical strategy, asserting "we feed the world" invokes neo-Malthusian fears to reposition differences in agricultural production systems within a moral framework where yield primarily determines agricultural legitimacy. This article ethnographically analyzes how this narrative intersects the lives and livelihoods of conventional and alternative farmers alike. Today, the narrative serves three functions: defending industrial agricultural systems against criticisms, justifying the pursuit of ever-higher yields on moral grounds, and gatekeeping agricultural legitimacy. Examining this discursive mechanism yields insight into the diversity of strategies through which actors within the industrial agricultural system reproduce particular land use practices in service of their own interests.
\end{abstract}

Keywords: Agriculture, development, agrarian change, narrative, industrialization, United States

\section{Résumé}

La production industrielle de céréales occupe la plupart des terres agricoles de l'Iowa. Aux abords des monocultures de maïs et de soja, cependant, de petits agriculteurs diversifiés établissent des exploitations agricoles alternatives et vendent sur les marchés locaux. Un récit, " nous alimentons le monde ", s'étend à travers ces deux sphères ; ses racines se trouvent dans la géopolitique de l'après-guerre, et ses itérations contemporaines reflètent les actions de groupes d'intérêts agricoles privés. En tant que stratégie rhétorique, affirmer "nous nourrissons le monde " invoque les craintes néo-malthusiennes pour repositionner les différences dans les systèmes de production agricole dans un cadre moral où le rendement détermine principalement la légitimité agricole. Cet article analyse ethnographiquement comment ce récit croise la vie et les moyens de subsistance des agriculteurs conventionnels et alternatifs. Aujourd'hui, le récit remplit trois fonctions : défendre les systèmes agricoles industriels contre les critiques, justifier la poursuite de rendements toujours plus élevés pour des raisons morales et garder la légitimité agricole. L'examen de ce mécanisme discursif permet d'appréhender la diversité des stratégies par lesquelles les acteurs du système agricole industriel reproduisent des pratiques particulières d'utilisation des terres au service de leurs propres intérêts.

Mots-clés: Agriculture, développement, mutation agraire, récit, industrialisation, États-Unis

\section{Resumen}

La producción industrial de granos ocupa la mayor parte de la tierra cultivable de Iowa. Sin embargo, a los alrededores de los monocultivos de soya y maíz, agricultores diversificados establecen operaciones agrícolas alternativas y venden a mercados locales. La narrativa, “nosotros alimentamos al mundo”, se extiende a estas

\footnotetext{
1 Dr. Andrea Rissing, President's Postdoctoral Scholar, School of Environment and Natural Resources, Ohio State University, USA. Email: rissing.4 "at" osu.edu. I would like to thank the farmers and agricultural professionals who shared their time over many conversations with me. Thanks to Hilary King, Yulia Chuvileva, and Sarah Franzen for many helpful discussions of these ideas, and my thanks as well to two anonymous reviewers whose generous comments improved this manuscript. Funding gratefully acknowledged from Wenner-Gren, USDA, NSF and Emory University.
} 
dos esferas. El origen de esta idea radica en la geopolítica del periodo posterior a la Segunda Guerra Mundial, y sus iteraciones contemporáneas reflejan las acciones de grupos con intereses agrícolas privados. A manera de estrategia retórica, la afirmación “nosotros alimentamos al mundo” evoca preocupaciones neo-Malthusianas para reorientar las diferencias entre sistemas agrícolas de producción dentro de un marco moral, en que la legitimidad agrícola es determinada primordialmente por la rentabilidad. Este artículo analiza etnográficamente, cómo esta narrativa entrelaza las vidas y modos de subsistencia tanto de agricultores convencionales, como alternativos. Hoy en día, la narrativa tiene tres funciones: defender los sistemas agrícolas industriales de sus críticas, defender en el ámbito moral la búsqueda de la mayor rentabilidad, y salvaguardar la legitimidad agrícola. Examinar este mecanismo discursivo, aporta nociones sobre la diversidad de estrategias a través de las cuales, actores dentro de los sistemas industriales agrícolas reproducen particulares prácticas de uso de la tierra en favor de sus propios intereses.

Palabras clave: agricultura, desarrollo, cambio agrario, narrativa, industrialización, Estados Unidos

\section{Introduction}

"But how do we end the 'we feed the world' mentality?" Rachel ${ }^{2}$ asked me, flipping a hamburger. The grass-fed patties sizzled on her stovetop as we whirred garden tomatoes in the blender for a lazy gazpacho. Outside her farmhouse, late summer dusk lingered on her organic vegetable fields and chestnut saplings. As we began cooking after a full day of working outside, our conversation had meandered to the question of how meaningful change could be created in Iowa's agriculture. Rachel wanted less of her state's valuable farmland used for large-scale grain production, and she worried that the "we feed the world mentality" worked against her goal.

From the earliest days of fieldwork, the words "feeding the world" appeared across my notebooks. I

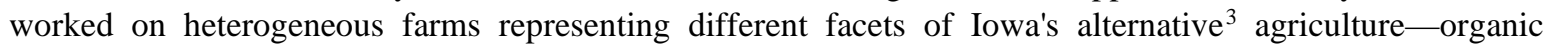
vegetable farms like Rachel's, heritage breed hog operations, orchards, artisanal dairies, farms rotating cattle on pasture. The phrase "feed the world" bridged disparate conversations, newspapers, local radio segments, agricultural events, and keynote speeches. It was as omnipresent as it was incongruous: every farmer with whom I worked sold their products exclusively to local markets-that is, they fed fellow Iowans, not the world. These farmers passionately described goals of farming in harmony with nature, engaging their local communities, growing healthy food, and building just food systems. Such values and motivations align their agendas with those of alternative agricultural producers in other parts of the United States (Bruce 2019; Galt et al. 2012; Paxson 2013; von Tscharner Fleming 2012; Weiss 2016).

Yet working to catalyze equitable, sustainable food systems in Iowa is a fundamentally different project than doing so in the Hudson Valley of New York or the Central Valley of California. The reasons for this are layered: ecological, cultural, political, economic. Regional variations in soil types and weather patterns mean growers adhere to different calendars and select different crop varieties. Historical variations in socio-economic contexts and labor management precedents affect a region's farm structure patterns (Pfeffer 1983). Political variations in agricultural sectors' constituent coalitions and relations influence growers' available opportunities, limits, and decisions (Darnhofer et al. 2019). Growers in the Hudson Valley or the Central Valley who oppose monocultural grain production do so from a distance. Growers like Rachel cannot consider industrial agrocommodity production an abstract threat; they share fence lines with these grain fields (Rissing 2019).

In 2019, like most years, Iowa ranked first in the country for corn, hog, laying hen, and egg production, and ranked second for soybean production (USDA NASS 2020). Public institutions, such as state agricultural research centers, and private institutions, such as commodity growers' associations, work with input suppliers and processors to expand the scale and profitability of grain production. Together, these organizations cultivate an industrial agricultural landscape that actively shapes the experiences of the new farmers with whom I worked, even as they seek to subvert its mandates. As Janssen (2017: 199) notes in the only recent ethnography of Iowa's

\footnotetext{
${ }^{2}$ All names are pseudonyms, some identifying details have been changed.

3 "Alternative food" is a notoriously inconsistent analytical concept (Tregear 2011). Here, I define alternative agriculture as growing food on a small scale for local markets using agroecological production practices.
} 
local foods movement, "Local food producers are simultaneously embedded in and separate from commodity agriculture." Invoking Malthusian logics, "we feed the world" is the ubiquitous discursive justification of industrial agriculture's practices, goals, and effects. This narrative's ubiquity also ensures it suffuses alternative agricultural spaces.

Ensuring sufficient nutritious calories for every person may require global coordination and cooperation. And yet, this is not really what "we feed the world" is about. This open secret weaves through agri-food systems literature. In passing, critical scholars acknowledge "feeding the world" as an ostensible goal more often pursued in service of corporate interests or productivism agendas than equitable global food security (Cadieux and Slocum 2015: 3; Glover 2010: 69; McMichael 2010: 610; Moragues-Faus and Marsden 2017: 276). This insight operates at the level of global policy, commodity trade, and transnational agribusinesses.

However, such viewpoints have not captured how this narrative intersects the work of people who grow the grain in question, or those committed to cultivating different Corn Belt futures. Keeping track of where and when I heard this narrative provided one of my first insights into the ways in which industrial agriculture's norms, expectations, and logics influence the experience of Iowa's new alternative farmers. Tracing "we feed the world" from my field sites backwards to its origins in $20^{\text {th }}$ century U.S. export policies showed how a politicized narrative's power transforms over time, remaking itself to affect agricultural ecologies around the globe, reminiscent of other powerful rhetoric's tangible effects on environments and agricultural livelihoods (Brosius 1999; Dove 1983).

This article ethnographically examines these intersections to illuminate the everyday discursive pathways helping reproduce the Corn Belt's current agricultural systems. In short, I take "we feed the world" seriously as a story that people in agriculture "tell themselves about themselves" (Geertz 1972), and I examine what this story accomplishes through its telling. I identify three functions this narrative serves: defending industrial agricultural systems against criticisms, justifying the pursuit of ever-higher grain yields on moral grounds, and delegitimizing alternative agricultural production.

Recently, scholars have called for political ecological interventions into critical food scholarship (Moragues-Faus and Marsden 2017) that prioritize the "systemic linkages between sustainable and unsustainable, mainstream and alternative, industrial and artisanal" (Besky and Brown 2015: 41), particularly in first-world contexts (Galt 2013). A political ecological approach helps reveal how powerful actors within the global system of commodity grain production reproduce the systems that uphold their interests through both material and rhetorical means. Industrial agriculture entrenches itself not only through corporate concentration and consolidation (Hendrickson 2015; Howard 2016), agribusiness lobbying (Baines 2015), or financialization of farmland (Ashwood et al. 2020), but also through the rhetoric deployed across its productive heart in middle America.

Classically, political ecological approaches focus on the place-specific determinants of environmental resource access and control, and the implications of these arrangements for ecologies and sustainable livelihoods (Robbins 2004; Watts 2000). I employ this lens to understand how the political networks of Iowa's agricultural institutions, rooted in $20^{\text {th }}$ century histories of the U.S. export-oriented food regime (Friedmann and McMichael 1989), continue to manifest landscape effects through gatekeeping agricultural legitimacy. In Iowa, the "we feed the world" narrative winds through large-scale and small-scale farms alike, farm loan offices and state fairs, equipment dealerships and 4-H shows ${ }^{4}$, grain elevators and farmers markets. As it connects these disparate places, it simultaneously propels and justifies commodity grain production's scale, practices, and purpose, to the exclusion of alternative agricultural possibilities.

The first half of the article briefly reviews the United States' $20^{\text {th }}$ century food aid policy regime to situate "we feed the world" within the geopolitical moment in which it arose. I then ethnographically track this narrative through agricultural sites across Iowa to understand its contemporary drivers and consequences. The ethnographic analysis primarily draws on over 16 months of fieldwork conducted between 2013 and 2016 across

\footnotetext{
${ }^{4} 4$-H shows are youth and children's development programs delivered by Cooperative Extension programs from more than
} 100 US universities. 
Iowa. From a home base in Ames, I completed 118 visits to 62 farms across the state; of these, 51 were beginning alternative farms. ${ }^{5}$ Day trips and overnight visits to farms typically entailed working alongside the farmer and/or their crew, joining in activities such as planting, harvesting, weeding, washing, delivering, milking, lambing, and moving livestock, as well as running deliveries and errands. Most farmers were in their '20s or '30s, and although most were married or partnered, only 14 farms were co-run by couples. Farms varied in how well-established their systems were. A few employed well-trained crews, were confident in their machinery skills, developed longstanding customer relationships, and owners had quit their off-farm jobs. Far more were still negotiating these and other aspects of farming as they worked to scale or intensify production. I also attended dozens of political rallies, fairs, conferences, field days, and potluck meals with farmers. To complement participant-observation, I conducted semi-structured interviews with 44 beginning alternative farm operators after working on their farms. ${ }^{6}$ Of the 51 beginning alternative farms on which I worked, roughly half $(n=26)$ were primarily or exclusively producing vegetables. The other half were split between livestock $(n=9)$, dairies $^{7}(\mathrm{n}=4)$, orchards $(\mathrm{n}=2)$, and diversified operations $(\mathrm{n}=10)$. I conducted follow-up visits to Iowa in 2017 and 2019.

\section{Corn Belt groundwork: soils, technologies, policies, and war}

"We feed the world" is indelibly connected to the yield-centric accounting which drives commodity grain production. When state and private interests alike frame the major agricultural project of our time as feeding the world's hungry, more calories seem always, simply, better. Iowa farmers excel at producing more calories. Corn, the state's primary grain commodity, boasts inherently high photosynthetic efficiency, helping establish it as a staple across the Americas (Warman 2003). For the last half century, concentrated research and development efforts have secured unprecedented yields from corn's sturdy botanical architecture. These projects have unfolded nowhere as successfully as in Iowa, where $20^{\text {th }}$ century agricultural technologies and U.S. policies map onto the region's glacial bequest of topsoil. "We feed the world" declares Iowa's position within global food systems. Employing soils, technologies, policies, and the post-WWII political moment as lenses helps explain how it came to occupy this position.

\section{Soils and technologies}

The Corn Belt one of the most fertile regions of the world. Although soil types across Iowa vary, the majority benefit from the loess deposited by a series of glaciers that moved across the state between 2.5 million and 500,000 years ago. Tallgrass prairie roots stretched ten or more feet underground and combined with the prairie's human, bison, insect, and microbial populations to transform loess into deep black topsoil (Mutel 2008). These rich soils provide a fertility boost, but today's yields owe more to the mechanical, genetic, chemical, and digital advances of the last century. The histories of $20^{\text {th }}$ century agricultural industrialization and corporatization are well-trodden (Barlett 1989; Fitzgerald 2003; Magdoff et al. 2000; Pollan 2006; Weis 2007); here, I briefly highlight the interconnected technological and political processes that have played out across Iowa's topsoil to produce its staggering harvests.

The U.S. government's forced removal of the Sauk, Ioway, and Meskwaki people from eastern Iowa in the 1830s (Mutel 2008) and John Deere's invention of the steel plow made possible the rapid transformation of Iowa's native ecosystem. By the end of the 1920s, tractors and combines had firmly established themselves on the Midwestern countryside. Early $20^{\text {th }}$ century Farmall tractors and Massey-Harris combine harvesters are the ancestors of the GPS-equipped tractors and 16-row combines that dotted Iowa's fields during my fieldwork.

\footnotetext{
${ }^{5}$ Following the USDA, I define "beginning farmer" as someone who has been principal operator of a farm for less than ten years.

${ }^{6}$ In addition to interviewing farm operators, I also interviewed people who had decided to quit farming ( $\mathrm{n}=12$ ), Farm Services Agency (FSA) managers ( $n=4)$, private agricultural bankers $(n=4)$, and parents of beginning farmers $(n=2)$.

${ }^{7}$ Because dairies are uncommon in Iowa, I considered even dairies selling bulk milk using conventional practices to be "alternative" for this study. Two of these four dairies self-identified with Iowa's sustainable agricultural movement and pastured their livestock, the other two did not.
} 
Today, these machines are supplemented by drones and other precision technologies creating new opportunities to profit from farm level data (Fraser 2019).

The adoption of mechanization advanced in fits and starts, not without pushback from farmers loath to purchase expensive machines whose internal combustion engines they lacked the skills to repair. It was not until WWI brought higher grain prices and shortages of labor and horses that tractor adoption took off in earnest (Fitzgerald 2003: 84-85). Combines caught on more slowly, but eventually they too took hold: between 1935 and 1945, the percentage of mechanically harvested corn grew from $15 \%$ to $70 \%$ in Iowa (May 1949, cited in Kloppenburg 2004: 117). After establishing their indispensability, these machines began affecting which crop species were developed, sold, and planted. Machines cannot accommodate much phenotypic diversity; they require straight rows of similarly sized plants maturing simultaneously (Kloppenburg 2004:116-117; Scott 1998: 266-268). Once machines replaced draft animals, larger field sizes laid the groundwork for two pairings of seed and chemical innovations that produced the skyrocketing agricultural yields of the latter $20^{\text {th }}$ century: hybrid varieties with chemical fertilizer, and genetically modified crops with pesticides.

Hybrid corn was first introduced to U.S. markets in the mid-1930s. Created by crossing corn plants whose respective lines had been self-pollinated for several generations, the resulting plants were genetically identical—ideal for mechanization—and higher yielding. An even more significant yield jump occurred after World War II when munitions plants began processing surplus ammonium nitrate into agricultural fertilizer. Ammonium nitrate fertilizer unlocked hybrid corn's latent yield potential. Between 1940 and 1950, the percentage of corn acres planted with hybrids increased from 15\% to 80\% (Kloppenburg 2004:106). By 1965, the Corn Belt's shift from open-pollinated varieties was almost complete: over $95 \%$ of all corn planted was hybrid (ibid: 91). Later in the $20^{\text {th }}$ century, the advent of genetic modification (GM) again revolutionized seed technology. Although GM technologies to improve nutritional profiles of staple foods received copious media attention-golden rice appeared on the cover of Time in 2000 - the bulk of the industry's investment focused on developing varieties resistant either to insects (i.e. Bt cotton) or herbicides (i.e. Round-up Ready soybeans) (Stone 2010).

These technological innovations made possible a new definition of agricultural success: ever-increasing crop yields. By this measure, Iowa's agriculture has never been more successful. In 1866, Iowa farms averaged 32 bushels of corn per acre (just under $2,200 \mathrm{~kg} / \mathrm{ha}$ ); by the beginning of the $21^{\text {st }}$ century, Iowa farms averaged $144 \mathrm{bu} / \mathrm{acre}(9,700 \mathrm{~kg} / \mathrm{ha})$. In 2016, for the first time, Iowa's average corn for grain yield topped $200 \mathrm{bu} / \mathrm{acre}$ (c.13,400 kg/ha), a milestone it again hit in 2017 (USDA NASS 2017).

\section{From technological innovation to rhetorical framing: Policies and war}

The mechanical, chemical, and genetic innovations of the $20^{\text {th }}$ century render plausible the idea that one region could singlehandedly produce enough food for all humankind. Malthusian assumptions about hunger's causes mapped onto post-World War II U.S. political interests to argue that it should. While technologies give Iowa grain producers the tools with which to coax an ever-larger harvest from their soil, it is the policy regimes under which they labor that have, first, incentivized such a project and, second, facilitated the global circulation of their products. During the seismic shift in the global political economic order that followed World War II, political rhetoric emerged alongside the country's new agricultural priorities that worked to frame exports as necessary for global food security.

From the late 1940s until the 1970s, U.S. agricultural and trade policies worked in conjunction with institutions of global governance to move surpluses of staple grains from the United States into developing countries in Africa, Asia, and Latin America. ${ }^{8}$ These efforts were a key component of U.S. Cold War imperialism, but their roots lie in earlier policy responses. During the post-war decades, the supply management policy enacted by the Roosevelt administration's 1933 Agricultural Adjustment Act (AAA) in response to the suffering of the Great Depression and Dust Bowl was still intact. Comprising price supports, which provided

\footnotetext{
${ }^{8}$ The agro-political histories briefly traced here focus primarily on the United States; the structural adjustment programs promoted by the World Trade Organization and the International Monetary Fund in the post-war years foretold the disastrous consequences for developing countries' agricultural economies (Bernstein 1990; McMichael 2009).
} 
artificially high prices for agricultural products, and production controls, which limited the number of acres on which farmers could plant, supply management policy was remarkably successful at encouraging farmers to grow as much wheat, corn, and soybeans as possible (Winders 2009a).

Following World War II, American farmers produced tremendous surpluses of all major commodities. This growth was incentivized by extant price supports and buoyed by wartime advancements in agricultural inputs. Between 1945 and 1970, national corn productivity more than doubled from 33 bu/acre (c. 2,200 kg/ha) to $72 \mathrm{bu} / \mathrm{acre}$ (c. 4,800 kg/ha) (Winders 2009a: 138). Although supply management was originally intended not only to increase farm incomes but also discourage overproduction, supply began to outstrip market demand. In the years following World War II, the federal government scrambled to pay for and store carry-over stocks of wheat, corn, and cotton, expenses to which the AAA had obligated them. While the growing livestock industry somewhat alleviated the oversupply of corn, wheat and cotton surpluses presented a serious, expensive problem.

To address this issue, the government sought and created new markets for American farms' products. The newly developed Bretton Woods systems of economic integration and the U.S. position of global dominance following WWII enabled this task. The 1948 enactment of the General Agreement on Tariff and Trade (GATT) also made this project easier by successfully liberalizing much of the post-war world economy. However, the GATT codified an important exemption for agricultural products. At the behest of a coalition of cotton and wheat growers' groups, the United States Department of Agriculture (USDA) and U.S. Congress had successfully pushed for the inclusion of Article XVI, which exempted agro-commodities from global bans on export subsidies (Winders 2009b). The United States' mid-century supply management programs thus continued to legally benefit American farmers and boost US agricultural production.

Global trade barriers were coming down exactly at the same time that U.S. agricultural yields began skyrocketing in earnest. Into this context, the Eisenhower administration's 1954 Agricultural Trade Development and Assistance Act established Public Law 480 (PL 480) and brought the sense of the 'greater good' to agricultural exports in the form of food aid. Where the Marshall Plan had sent resources such as fertilizer along with food to help western European countries re-establish their own agricultural sectors following WWII, PL 480 targeted developing countries and sent food alone (Friedmann 1982). Eleven years after PL 480's introduction, the United States was responsible for the "vast majority" of the world's \$1 billion in food aid (Winders 2009a: 149). An influx of cheap agro-commodities during the PL 480 years undercut smallholder livelihoods and the traditional agrarian systems of receiving countries across Africa, Latin America, and Asia (Friedmann 1990; Garst and Barry 1990). By 1968, nearly 80 percent of all U.S. agricultural exports was food aid destined for countries in the global South (Friedmann 1982: 265). As formerly self-sufficient countries became reliant on imports, the United States cemented its dominant export position within global agricultural trade (Friedmann and McMichael 1989; McMichael 2009).

As the blueprint for enduring inequity in international relations, this process was described by its U.S. architects as "feeding the world." American politicians enacted this version of food aid not only as a costeffective strategy for managing surpluses, but also as a method for engendering certain types of political relationships with developing countries. Fears of communism spreading were rampant, and agricultural exports, both food aid and Green Revolution technologies, were intended not only to relieve suffering, but also to secure poor countries' allegiances (Cullather 2010; Patel 2007; Perkins 1990). Later in the twentieth century, Richard Nixon's Secretary of Agriculture Earl Butz expressed the strategic role of food aid by observing, "Hungry men listen only to those who have a piece of bread. Food is a tool. It is a weapon in the U.S. negotiating kit" (Patel 2007: 91).

Over the latter $20^{\text {th }}$ century, U.S. agricultural policy shifted in response to mounting liberalization efforts. Yet export subsidies remained steadfast throughout the Nixon administration's Agriculture and Consumer Protection Act, the Export Enhancement Program of the 1985 Food Security Act, and the 1996 Federal Agriculture Improvement and Reform Act (Winders 2009a). Authoring the rules of global trade presented another opportunity for the United States to bolster its own economic interests during the GATT's 1994 Uruguay Round, when the World Trade Organization (WTO) replaced it as the primary intergovernmental trade regulator. Where the GATT had exempted agriculture sectors from trade regulation, the WTO—pressured by both neoliberal policy advocates and global trade critics—sought to extend mandatory trade liberalization to 
agriculture through its Agreement on Agriculture (AoA) (Holt Giménez and Shattuck 2011; McMichael 2001; Weis 2007). In the 1990s, the development benefits of trade liberalization, free markets, and open borders were taken as gospel by the officials drafting the agreement. Political discourses forcefully linked liberalizing trade to food security, with the United States arguing that a "smooth-functioning world market" offered the best way to meet human food needs (Ritchie 1993, quoted in McMichael 2001: 217). These explanations occurred following a decade of structural adjustment policies, often decimating local food production and increasing food aid dependence (Walton and Seddon 1994). In pursuit of these goals, the AoA steeply curbed governments' abilities to limit agricultural imports. Quotas were no longer permitted, and tariff limitations were capped. Yet the AoA also codified a tapestry of loopholes and exceptions. These permitted "blue box" and "green box" agricultural subsidies. These, such as state support for research, infrastructure, crop insurance programs, marketing supports, certain direct payments to farmers, and conservation programs - helped the European Union and the United States support their own farmers and pursue ever-higher yields (Weis 2007). By strategically differentiating prohibited "trade distorting" from allowable "non-trade-distorting" subsidies, the AoA's authors created "a system of agricultural supports that, in essence, let them continue to subsidize their farmers, while countries in the Global South signed away precisely this right" (Patel 2007: 97).

The United States began "feeding the world" in the 1940s through an aggressively subsidized food aid program with politico-ideological motivations. Since the post-war inception of targeted food aid, the contours of both U.S. domestic agricultural policy and the global trade landscapes have shifted drastically. Today, protectionist and populist sentiments are mounting in response to these histories (Gusterson 2017), yet the United States remains a net exporter of agricultural commodities (Daughterty and Jiang 2019). Across decades of structural changes, "we feed the world" accompanied U.S. exports, an assertion that at once claims overproduction as an unassailable moral project and encapsulates a world order.

\section{Has the world been fed?}

Since its emergence, "We feed the world" has become the preeminent script of the Corn Belt. As articulated by Vanclay and Enticott (2011: 260), a script is a "culturally shared expression", appropriate and expected in certain social contexts, which provides "a rationale or justification for a particular issue or course of action." Seeing "we feed the world" as this kind of script sheds light on much of the work that it does while traveling; as a narrative, it provides an airtight justification for and defense of large-scale, high yield grain production. In making this defense, this script offers conventional grain producers language with which to explain and honor their livelihoods. Scripts offer one way of perceiving agriculture as social presentation, as responsive and embedded human activities through which farmers and others perform their identities (Flachs and Richards 2018).

In both mid-century and current agricultural discourses, an unstated Malthusian logic, one that understands shortages as the root of hunger, underwrites the script. This view misrepresents the causes of famine by obscuring the crucial roles of income and distribution in food access (Sen 1977), but, as in the $18^{\text {th }}$ century (Malthus 1798) and 1960s (Ehrlich 1968), provides an eminently persuasive rhetorical tool. Through this script, growing more food becomes a project of utmost urgency, particularly in the context of a growing global population. These assumptions propel "we feed the world" across Iowa's landscapes with sufficient force to distance its political histories and transmute its meanings.

Before analyzing this narrative's contemporary iterations, it is helpful to briefly name and unpack its assumptions. Two key problems undermine the logic of "we feed the world" as it exists in Iowa. First, Iowa predominantly produces grain, not foodstuffs. Most field corn is not consumed by humans. After harvest, forty percent of U.S. corn is converted into ethanol for fuel and thirty-seven percent is processed into livestock feed (Mumm et al. 2014). Less than eleven percent of this grain is eaten by humans, most often in the form of highly processed oils, additives, and sweeteners (Pollan 2006). Although people eat the livestock that consume grain, growing grain to fatten animals, particularly ruminants, is an inefficient use of land and resources. Skyrocketing yields do not assuage world hunger, but they do reliably provide cheap grain inputs, providing outsize benefits to agribusiness within the "agro-trader nexus" (Baines 2015) and exacerbating political-economic inequalities in industrial agriculture (Gillon 2010). 
Yet when the Corn Belt discusses its own agriculture, the emphasis remains squarely on feeding people. Iowa State University hosts "Feeding the World" seminar series. ${ }^{9}$ Headquartered in Des Moines, the World Food Prize's Iowa Hunger Summit addresses global food insecurity while "honoring the role Iowans play in feeding the world. " ${ }^{10}$ Recent Iowa Farm Bureau blog posts celebrate U.S. agricultural dominance by reminding readers that "one American farm today feeds 166 people in the United States and abroad, compared to just 26 people in 1960" (Bjork 2019) and that "experts estimate that we'll need to double agricultural output through productivity growth to feed a world population of nearly 10 billion in 2050" (Bader 2019). Such messages cast yield-focused agricultural accounting as moral projects undertaken on behalf of all the world's eaters, obscuring the actual destinations of Iowa's inherently flexible grain commodities (Gillon 2016).

Second, Malthusian perspectives fail to sufficiently explain global food shortages. Global caloric production is already more than sufficient feed the world's population, and yet hunger persists. Measuring caloric output of different production systems is a notoriously difficult task. It is dependent not only on inputs, but also variables such as climate, weather variations, rotation, and varieties. In Iowa, growers generally recognize that conventional grain yields outpace organic yields. Meta-analyses of studies comparing organic and conventional systems bear this observation out, but with the caveat that practices such as crop rotations, multi-cropping, and integrating perennials can significantly reduce yield gaps (Ponisio et al. 2014; Seufert et al. 2012). Although the conventional-organic yield gap has attracted copious academic attention, it is also less relevant than it may initially seem. Regardless of the yield gap, modern organic systems can produce sufficient calories to feed the world's population. On average, adult humans require between 2,200 and 2,500 calories daily. Using average yield ratios, University of Michigan researchers modeled how many calories could be produced through organic methods on the current land in agricultural use. Depending on model assumptions, predicted organic yield ranged from 2,641 calories to 4,381 calories per person, per day (Badgley et al. 2007). Especially considering that organic yields would likely increase over time as soil organic matter increased, the assertion that organic agriculture cannot feed the world is tenuous. Recently, Wilbois and Schmidt (2019) have argued that conventional agriculture's benchmarks may not even be a useful judge of organic agriculture's potential. They advocate moving from the question, "can organic agriculture feed the world?" towards discussing, "how can organic agriculture contribute to feeding the world?" This useful reframe also subtly challenges the project of one group of farmers trying to feed all people.

As a narrative, asserting "we feed the world" glosses these complexities while staking a moral claim. It also provides an ironclad ideological explanation for the state's sheer scale of production. To this point, Comito et al. (2013) argue that Iowa grain farmers can feel trapped between two competing identities: 1) farmers as stewards of the land, and 2) farmers as shrewd businessmen. Good stewards take care of the land for future generations, good businessmen maximize profits. These two agricultural goals often appear at odds. Comito et al. identify a new cultural role-farmers as heroes who feed the world - that resolves this tension by imparting a sense of the "greater good" to yield maximization (ibid). Building on these insights, I turn now to ethnographically chart this narrative across a range of agricultural spaces to understand the full scope of its prominence and consequences.

\section{3. "We Feed the World" today}

Today's cultural moment differs markedly from the post-war years in which the United States invented food aid as a political tool. Contentious political debates center not on threats of communism's infiltration, but on progressive vs. conservative visions for the country's future. In this space, "we feed the world" has transformed in the lives of the people who produce grain. This narrative now functions as a strategic assertion that defends industrial agricultural practices against a range of criticisms and turns yield into a moral yardstick. Iowa is home to many types of agriculture, and emergent alternative farms often employ different metrics than yield—such as human nutrition, soil organic matter content, or healthy wildlife populations — to judge their

\footnotetext{
${ }^{9}$ See, for example, https://www.ans.iastate.edu/feeding-world-seminar-series-fall-2017.

${ }^{10}$ See

https://www.worldfoodprize.org/index.cfm/87428/46763/the_world_food_prize_foundation_opens_registration_for_the_a nnual_iowa_hunger_summit
} 
successes (Bell 2004; Janssen 2017). The narrative inverse-"you can't feed the world farming like that"—also delegitimizes alternative agricultural visions of smaller-scale, diversified agricultural futures for the Corn Belt.

\section{Narrative defenses and moral contests}

Many conventional farmers in the Midwest feel that their profession is under attack by agriculturally illiterate city folks, government bureaucrats, and activists. This perception is fueled, in part, by the way the Iowa Farm Bureau and other institutions frame the unfolding national conversations about food systems. In December of 2015, I attended the Iowa Farm Bureau's annual meeting in Des Moines. I arrived a bit late the second day, around 8:30 in the morning, just in time to catch the end of a speech. On stage, the speaker powered through slides showing the covers of many books and films on food systems, food politics, and food "fights", including works such as Robert Kenner's Food Inc., Christopher Leonard's The Meat Racket, Sanjay Rawal's Food Chains, Barry Estabrook's Tomatoland, Kip Andersen and Keegan Kuhn's Cowspiracy, and Kristin Canty's Farmageddon. The last decade had seen a barrage of such agricultural exposés that highlight industrial practices and critique them on environmental, health, and social justice grounds. After clicking through dozens of these slides to convey the sheer volume of the attack, the speaker told his audience of farmers that they were "being portrayed as a bigger threat than Osama bin Laden." He said that it was "unfortunate that people think that they need to place a villain's mask on farmers" and assured the assembled farmers that the Farm Bureau was engaged on all fronts to counter these "fraudulent claims."

This narrative of shared victimhood and promise of organizational protection evokes the "Pride in Tobacco" campaign sponsored by the corporation R.J. Reynolds in the 1970s. Through brochures, billboards, and sponsored meals with corporate representatives, the campaign taught southern tobacco growers that together they were a "tobacco family" under attack from public health advocates (Benson 2011). Forty years later, the Iowa Farm Bureau is using a similar strategy of inculcating loyalty by claiming to guard against unjust accusations, not from public health advocates, but animal rights activists and others perceived as out-of-touch urban elites.

This sense of being under attack resonates with young grain farmers. Bryce, who grows corn and beans with his grandfather, showed me around his farm and expressed unprompted frustration that all it takes is one viral video of a man beating a hog, and suddenly "we're all bad people." In a different part of Iowa, Marvin told me about how he feels like he is "under a microscope" and how improved consumer education would prevent city people from demanding laws that hurt farmers. Using similar language to Bryce, Marvin, who also produces grains, told me quietly, "We're not these evil people that we're made out to be." I find it significant that Bryce and Marvin both brought up these feelings within a couple hours of meeting me. Although it was never explicitly stated, I perceived an ongoing tension during fieldwork regarding whether or not I, by all appearances an academic lacking any real farming background, was writing yet another scathing critique of the system in which Bryce and Marvin took pride, had grown up, and through which they supported their families.

A founding pillar of what Jeanette Catsoulis (2010) dubbed the "what's-the-matter-with-corn-syrup?" film genre, Robert Kenner's 2008 Food, Inc. is one of the best-known popular critiques of industrial food systems. Primarily relying on the expertise of food journalists Michael Pollan and Eric Schlosser, the film problematizes several aspects of American food production, including the reliance on corn for livestock feed, vertical integration of food corporations, and lack of food safety oversight. Kenner paints a somewhat apocalyptic view of industrial agriculture in the United States, and the film closes with animated intertitles rolling across the screen; as Bruce Springsteen's "This Land is Your Land" plays, the audience reads:

Buy from companies that treat workers, animals, and the environment with respect. When you go to the supermarket, choose foods that are in season. Buy foods that are organic. Know what's in your food. Read labels...The average meal travels 1,500 miles from the farm to the supermarket. Buy foods that are grown locally. Shop at farmers' markets. Plant a garden. (Kenner 2008) 
These "vote with your fork" commandments have guided much of the "locavore"11 movement (DeLind 2011; Weiss 2016). Such imperatives unambiguously tell consumers to boycott products containing ingredients from farms like Bryce and Marvin's. I believe that this tension-that food celebrities often condemn conventional food production and praise small-scale, low-input production-underpinned much of the frustration experienced by conventional growers. From their perspective, and from the perspective of Iowa's dominant metrics for judging agricultural success, such small "market gardens" were inefficient and unproductive, more "hobby farm" than "real farm." Yet these were the sorts of farms enjoying a moment of fame and receiving heaping praise from chefs, authors, and other elite voices.

The perception of being under attack also echoes sociologist Arlie Hochschild's (2016) findings from fieldwork among far-right and Tea Party conservatives in Lake Charles, Louisiana. An informant of Hochschild's who was an active church member and dedicated mother told her of feeling as though "liberals" constantly lobbed insults at her communities, calling people like her "ignorant, backward, rednecks, losers" (ibid: 23). Feeling like Michael Pollan thinks you are an "evil person" because you grow corn may be the agricultural version of the class and political divisions currently crisscrossing the country. Similarly, Food Inc. and other critiques of industrial agriculture resonate, in conventional agricultural circles, not as critiques of a corporate system that has been eking away at farmers' independence for decades, but as attacks on their families' hard work and pride.

Promoted by Iowa's prominent agricultural organizations, "we feed the world" powerfully deflects such criticisms of industrial agriculture's environmental, social, and health effects. These organizations also actively reinforce "feeding the world" as a point of pride. The Iowa Farm Bureau's presence was strongly felt at the 2015 Iowa State Fair. In a central building there, several full color display boards featured photos of Iowa farmers with the text, "It takes an Iowan" superimposed over their images. Next to the photos of smiling young farmers, one board read:

Our Evolving Role in Feeding the World: Feeding the world is no small task. And with the global population predicted to hit nine billion by 2050, it's a task that requires a unique group of people. People driven by ingenuity, determination, and humanitarianism who are leaders in both education and agriculture. And aren't afraid to roll up their sleeves. We are Iowans-leaders in feeding the world.

Although the alternative farmers with whom I attended the fair rolled their eyes and dismissed such signs as "propaganda", such media was an atypical pathway for "we feed the world" to intersect alternative farmers' livelihoods. This ubiquitous narrative more often appeared in everyday conversations. Seemingly any topic even tangentially related to farming could quickly pivot to land on "feeding the world." In line at a conventional farming conference, I met a friendly 72-year old woman who had been raising cattle with her husband for decades. Looking my friend and I up and down, she called us "city folks" and invited us to ask her any questions we had about farming. I think she meant her invitation to start a conversation about production practices, but I asked her about how farming had changed since she started decades ago. She started talking about technologythe machines are bigger, she said, and more expensive, and more efficient. Quickly, however, and without any additional questioning on my part, this led into a tangent on the "responsibility" she and her husband feel to "feed the billions of souls" in the world.

Such references, oblique and explicit, to a world full of people who would go hungry without action by American farmers also wove through conversations with professionals in agriculture-adjacent spaces. During the winter of 2015, I spent a couple of days shadowing a dairy nutritionist. We would meet at dawn in a small town's gas station parking lot. I would leave my Prius in a corner of the parking lot, and we would drive together in his truck to visit three or four small-to-medium sized dairies. At these dairies, the nutritionist reviewed production records, examined the herd and silage stores, read water reports, broke apart and inspected dried cowpies, and advised farmers on their nutritional supplements. These dairies - somewhere between 100 and 300 cows, primarily family labor, sometimes growing their own feed, but not direct-marketing or grazing on

\footnotetext{
${ }^{11}$ In 2007, the New Oxford American dictionary named "locavore" as the word of the year (OUP Blog, 2007).
} 
pasture-are uncommon in Iowa. This nutritionist was a hero to the farmers who hired him; one told me that none of her calves had died since he tweaked her mineral ratios.

As we drove between farms, he explained that his overarching goal was to help independent, familyowned dairies stay in business. He thought he could help them find efficiencies and cost-saving techniques that would help them compete with what he called "the big guys." He advocated for independent farms, cover crops, humane treatment of animals, and soil practices that support microbial diversity, but when the topic of organic agriculture came up, his face darkened. In measured sentences, he told me that he knew a lot of people who thought organic agriculture was the future, but he was unconvinced. Organic agriculture might work for some folks, he said, but it can't feed the world. With conviction, he told me that if everyone went organic, a lot of people would starve.

Another time, a quarter mile off the highway, I walked into a plain building with a single American flag waving on a pole in the parking lot. This building, the only structure visible among corn fields, housed the county's Farm Services Agency, a branch of the USDA to which many beginning famers turn for farm loans. I had an interview arranged with one of the loan managers. Young farmers had been telling me that they quit farming because of family stress, physical exhaustion, financial struggles, and marital difficulties, and I was curious to hear his take on farm exits. He quickly connected even this issue to food security. He told me,

They just quit because they get burned out. It's so much physical labor with those nonmechanized, you know, there's a reason why people use herbicides and pesticides. The sheer labor aspect of it is just immense. Especially if you want to feed the masses, you're never going to be able to do that.

This loan manager's transformation of my question regarding why some young farmers quit into a non-sequitur assertion that feeding the masses is impossible without chemical inputs, signaled to me the extent to which the "we feed the world" narrative has saturated the way Iowans think about and discuss agricultural production.

This sentiment also echoed language I had heard earlier at an Iowa Farm Bureau Economic Summit. During this two-day summit, an audience of primarily farmers filled a windowless auditorium on Iowa State University's campus to listen to a series of primarily non-farmer experts. One speaker, a regional sales manager for a farm management firm, started off presenting on recent trends in Iowa's farmland pricing, but quickly shifted gears to speak extemporaneously about propaganda campaigns run by environmental activists. He affirmed that he knew every farmer in the room cared about water quality and stated that proposed EPA clean water regulations "scare[d] him to death" before pivoting again to talk about organic agriculture. "If we go back to organic agriculture", he said, only four or five billion people could be fed. This language reproduces nearly verbatim Malthusian discourses from the 1970s, when Secretary of Agriculture Earl Butz stated, "Without the modern input of chemicals, of pesticides, of antibiotics, we simply could not do the job. Before we go back to an organic agriculture in this country, somebody must decide which 50 million Americans we are going to let starve or go hungry" (Belasco 2006: 119).

Scripts do not develop by themselves, and understanding how this narrative animates Iowa agriculture also requires attending to the power dynamics governing its strategic deployment in promotion of certain types of agricultural interests. In their explication of scripts and megascripts, Vélez-Ibáñez and Sampaio (2002) center the interplays with power. Through scripts, "power becomes articulated and rationalized" (Vélez-Ibáñez 2010: 197, n1). Through repetition, the "we feed the world" narrative becomes a discursive touchstone that, with every invocation, casts corporate extraction and ecological degradation as the greater good. Claiming to "feed the world" also claims a position of power, a maneuver accomplished in part through gatekeeping agricultural legitimacy and restricting it to the kinds of large-scale, specialized production on which transnational agribusinesses depend.

"We feed the world (and you don't)": an industrial narrative on alternative farms

Temporal framings such as "going back" position organic agriculture as something that predates conventional agriculture, something out of which today's agriculture grew but which it has unquestionably surpassed. This judgement is only exacerbated for farms that are small-scale, low-input, and human-powered, 
as were the majority of farms on which I worked. These kinds of farms grow fruits, vegetables, eggs, and meat for the communities in which they live while minimizing or eliminating chemical and fossil fuel inputs. They also seek to effect positive environmental changes on and around their farms, such as by planting prairie species to nurture pollinator populations and integrating compost to reduce waste while increasing soil organic matter content. Food journalists and celebrity chefs herald this type of farm as a primary force behind the "good food movement." However, many people with whom beginning alternative farmers interact in their day-to-day lives carry different judgements on the value of their farms. From a perspective that holds industrial agriculture "feeds the world", small-scale, direct-market agriculture can be dismissed as insufficiently global, affordable, or efficient. Beginning alternative farmers encounter "we feed the world" through the judgement, "you can't feed the world", communicated both overtly and subtly by neighbors, lenders, and other farmers.

For example, Amanda raises heritage livestock for local markets. After spending her twenties and early thirties on the east coast in a high-powered corporate workplace, she was ready to pursue what she described as "a more honest career" in farming. When she moved back to Iowa to start her farm, she attended a couple of county meetings aimed at beginning farmers. Most of the other attendees were young grain farmers. People told her, "You can't feed the world the way you're farming", and criticized her food as unaffordable after hearing about her production systems. She stopped attending these meetings shortly after she started, preferring instead to draw community from likeminded alternative farmers even if they lived hours away.

Mark, who runs a small vegetable farm and sells through farmer's markets and a Community Supported Agriculture (CSA) program, similarly told me, "I hear a lot [of] criticism, this isn't, you're not feeding anyone, this is small scale, you're serving affluent customers." For Mark, the idea of who could or could not "feed the world" became particularly insidious when talking about agricultural technologies. Towards the end of our conversation, he described his operation as an "appropriate technology" (Schumacher 1973) model of agriculture, one that balances technology with hand work. He continued, "I actually think that's a lot more applicable to feeding the world than heavily capital intensive, technological [systems]. You know what I mean? They're saying, that's what is going to feed the world, and I'm thinking, like $90 \%$ of the farmers in the world look a lot more like what I'm doing."

The assertion, which at times almost seems like an accusation, that small-scale, low input agriculture is incapable of "feeding the world" is a primary critique levied at alternative farmers by individuals in the industrial system. Many beginning alternative farmers are deeply committed to social justice aims and worry that the prices they charge to cover their unsubsidized costs makes their food inaccessible to low-income consumers. Alternative producers know that their products are worth how much they charge. They also know that their comparatively higher prices represent their exclusion from the complex network of subsides that keep conventional food cheap, and that millions of people around the world feed themselves and their communities through small-scale, low-input, diversified production. Yet even with these understandings, new farmers can still feel guilty if they rely on wealthy urban consumers. This concern means "you can't feed the world the way you're farming" can land squarely and exacerbate new farmers' self-doubts. One farmer with whom I worked seemed to have internalized this critique so much that, during a farm tour, he repeatedly asked me, why are we only feeding rich people? Over and over, he anxiously asked, "What are we even doing?" The tension between charging premium prices while living on subsistence wages came up often among farmers struggling with the economic inaccessibility of their products.

In Iowa, this narrative functions as a rhetorical strategy that positions different scales of production within—and confines them to-a Malthusian framework. It recasts farming as a moral contest where yield always trumps all, and industrial production always wins when the metric is yield. Market gardens or hobby farms are not bad, the subtext goes. But they are also not as serious, significant, or honorable as the large-scale farms keeping food in the pots of the world's hungry. Small-scale, alternative growers are sensitive to this critique, especially when coupled with commentary on the price of their food or an implication that they only grow food for rich people. This assertion simultaneously defends conventional production and carries negative judgments on the wisdom, viability, and worth of alternative agriculture. Growing on acreages around the edges of commodity production, alternative farmers already occupy marginal positions within Iowa agriculture. When "we feed the world (and you don't)" appears at their farm gates, one effect is to re-entrench this marginality. 


\section{Discussion and Conclusions}

Since the mid-twentieth century, the "we feed the world" narrative has accompanied cheap exports as they disenfranchised smallholder farmers around the world. Today, in the heart of the Corn Belt, asserting "we feed the world" conjures beneficence in the face of undeniable environmental degradation and reinforces a Malthusian perspective that equates high yields with moral outcomes. In conventional agricultural spheres, this narrative creates a sense of shared identity and purpose. Simultaneously, it works to delegitimize Iowa's emergent small-scale, diversified farms, whose scales, markets, and practices misalign with industrial agricultural systems.

As a script working across and between Iowa's conventional and alternative agricultures, the "we feed the world" narrative connects ostensibly distinct production realms. "We feed the world" appears within conventional agricultural spaces partially in response to critical commentary from alternative food spaces, then migrates back across production spaces to affect how beginning alternative farmers conceptualize their own livelihoods. When people who work in or around industrial agriculture tell alternative growers, "you can't feed the world farming like that", this critique is partially a symptom of the frustration they feel as increasingly denigrated actors. Like all people seeking to break new ground, beginning alternative farmers confront an already-active landscape, and they must contend with its imbued ecological and cultural histories. Navigating these political-ecological contexts in Iowa means confronting a sprawling system of commodity grain production whose institutions work to limit agricultural legitimacy to the kinds of large-scale, specialized production on which transnational agribusinesses depend.

Tracing this narrative as a cultural script also means recognizing its dynamism and conflicts, recognizing "both agency and internalization, both resistance and accommodation in the same space and place" (Vélezibáñez and Sampaio 2002: 16). The "we feed the world" narrative is not uncontested in Iowa. In 2001, when Governor Tom Vilsack called for Iowa to become the "food capital of the world", local food activists called for Iowa to first become the food capital of Iowa (Hinrichs 2003: 41). Just as "we feed the world" transforms into "you can't feed the world farming like that", as a defensive statement, so too does it transform into "you can't feed the world feed corn" as a subversive one. "Feeding the world" evokes pride in many agricultural spaces but is met with ire in others. Even at Iowa State University, Iowa agriculture's geographic and symbolic heart, college students call attention to the state's own ongoing struggles with food insecurity and protest opaque trials of genetically engineered foods promising to feed developing countries (Dubisar and Roesch-McNally 2018; Kruzic et al. 2016). People who establish alternative farms in Iowa confront challenges particular to their proximity to industrial farms, but this proximity also grants unparalleled insights into how the system they seek to change functions. Many Iowans critique industrialization's effects at home and downstream, and many Iowans have been working for decades to change the narrative. When the state legislature announced plans to defund Iowa State University's Leopold Center for Sustainable Agriculture, an outpouring of statewide protests arose (Carter et al. 2018). While defunding happened, the Centre was not closed down. These spaces of counterhegemonic resistance continue to transform "we feed the world."

Since its inception in twentieth century food aid policies, "we feed the world" has remained industrial agriculture's axiom, acquiring new meanings and effecting different consequences over time while remaining constant in its promise. In conclusion, I offer perhaps the most cogent critique of this dynamic I have ever heard, a winking question, wryly posed to me by a frustrated vegetable farmer: "What sin can you not commit in the name of feeding the world?"

\section{References}

Ashwood, L., Canfield, J., Fairbairn, M., \& De Master, K. (2020). What owns the land: the corporate organization of farmland investment. Journal of Peasant Studies, (614). https://doi.org/10.1080/03066150.2020.1786813

Bader, Z. (2019). Why America needs more locally-grown (and globally-sustainable) food. Retrieved November 2, 2020, from Iowa Farm Bureau Blog website: 
https://www.iowafarmbureau.com/Article/Why-America-needs-more-locallygrown-andgloballysustainable-food

Badgley, C., Moghtader, J., Quintero, E., Zakem, E., Chappell, M. J., Avilés-Vázquez, K., ... Perfecto, I. (2007). Organic agriculture and the global food supply. Renewable Agriculture and Food Systems, 22(2), 86-108. https://doi.org/10.1017/S1742170507001640

Baines, J. (2015). Fuel, feed and the corporate restructuring of the food regime. The Journal of Peasant Studies, 42(2), 295-321. https://doi.org/10.1080/03066150.2014.970534

Barlett, P. F. (1989). Industrial agriculture. In S. Plattner (Ed.), Economic anthropology (pp. 253-291). Stanford University Press.

Belasco, W. J. (2006). Appetite for change: How the counterculture took on the food industry. Cornell University Press.

Bell, M. (2004). Farming for us all: practical agriculture and the cultivation of sustainability. Pennsylvania State University Press.

Benson, P. (2011). Tobacco capitalism: growers, migrant workers, and the changing face of a global industry. Princeton University Press.

Bernstein, H. (1990). Agricultural 'modernisation' and the era of structural adjustment: Observations on subSaharan Africa. Journal of Peasant Studies, 18(1), 3-35. https://doi.org/10.1080/03066159008438441

Besky, S., \& Brown, S. (2015). Looking for Work: Placing Labor in Food Studies. Labor Studies in WorkingClass History of the Americas, 12(1-2), 19-43. https://doi.org/10.1215/15476715-2837484

Bjork, T. (2019). Farmers shouldn't forget how valuable they are. Retrieved November 2, 2020, from Iowa Farm Bureau Blog website: https://www.iowafarmbureau.com/Article/Farmers-shouldnt-forget-howvaluable-they-are

Brosius, J. P. (1999). Green dots, pink hearts: displacing politics from the Malaysian rain forest. American Anthropologist, 101(1), 36-57. https://doi.org/10.1525/aa.1999.101.1.36

Bruce, A. B. (2019). Farm entry and persistence: Three pathways into alternative agriculture in southern Ohio. Journal of Rural Studies, 69(April), 30-40. https://doi.org/10.1016/j.jrurstud.2019.04.007

Cadieux, K. V., \& Slocum, R. (2015). What does it mean to do food justice? Journal of Political Ecology, 22(1), 1-26. https://doi.org/10.2458/v22i1.21076

Carter, A., Chennault, C., \& Kruzic, A. (2018). Public action for public science: Re-imagining the Leopold Center for Sustainable Agriculture. Capitalism, Nature, Socialism, 29(1), 69-88. https://doi.org/10.1080/10455752.2017.1423364

Catsoulis, J. (2010, April 9). What's the matter with corn syrup? The New York Times, p. C12. Retrieved from http://www.nytimes.com/2010/04/09/movies/09fresh.html

Comito, J., Wolseth, J., \& Morton, L. W. (2013). Stewards, businessmen, and heroes?: Role conflict and contradiction among row-crop farmers in an age of environmental uncertainty. Human Organization, 77(4), 283-292.

Cullather, N. (2010). The hungry world: America's Cold War battle against poverty in Asia. Harvard University Press.

Darnhofer, I., D'Amico, S., \& Fouilleux, E. (2019). A relational perspective on the dynamics of the organic sector in Austria, Italy, and France. Journal of Rural Studies, 68(December 2018), 200-212. https://doi.org/10.1016/j.jrurstud.2018.12.002

Daughterty, K., \& Jiang, H. (2019). Outlook for U.S. Agricultural Trade, AES-110. Retrieved from https://www.ers.usda.gov/webdocs/publications/95477/aes-110.pdf?v=4497.5

DeLind, L. (2011). Are local food and the local food movement taking us where we want to go? Or are we hitching our wagons to the wrong stars? Agriculture and Human Values, 28(2), 273-283. https://doi.org/10.1007/s10460-010-9263-0

Dove, M. R. (1983). Theories of swidden agriculture, and the political economy of ignorance. Agroforestry Systems, 1(2), 85-99. https://doi.org/10.1007/BF00596351 
Dubisar, A., \& Roesch-McNally, G. (2018). Representation, resistance, and rhetoric: Bananas catalyze campus activism. Present Tense, 7(1).

Ehrlich, P. (1968). The population bomb. Sierra Club.

Fitzgerald, D. K. (2003). Every farm a factory: The industrial ideal in American agriculture. Yale University Press.

Flachs, A., \& Richards, P. (2018). Playing development roles: The political ecology of performance in agricultural development. Journal of Political Ecology, 25(1), 638-646. https://doi.org/10.2458/v25i1.23089

Fraser, A. (2019). Land grab/data grab: precision agriculture and its new horizons. Journal of Peasant Studies, 46: 5, 893-912. https://doi.org/10.1080/03066150.2017.1415887

Friedmann, H. (1990). The origins of third world food dependence. In H. Bernstein, M. Mackintosh, \& C. Martin (Eds.), The food question: profits versus people (pp. 13-31). Earthscan.

Friedmann, H., \& McMichael, P. (1989). Agriculture and the state system: The rise and decline of national agriculture, 1870 to the present. Sociologia Ruralis, 29(2), 93-117.

Galt, R. E. (2013). Placing food systems in first world political ecology: A review and research agenda. Geography Compass, 7, 637-658. https://doi.org/10.1111/gec3.12070

Galt, R., O'Sullivan, L., Beckett, J., \& Hiner, C. (2012). Community Supported Agriculture is thriving in the Central Valley. California Agriculture, 66(1), 8-14. https://doi.org/10.3733/ca.v066n01p8

Garst, R., \& Barry, T. (1990). Feeding the crisis: U.S. food aid and farm policy in Central America. University of Nebraska Press.

Geertz, C. (1972). Deep play: notes on the Balinese cockfight. Daedalus, 101(1), 1-37.

Gillon, S. (2010). Fields of dreams: Negotiating an ethanol agenda in the Midwest United States. Journal of Peasant Studies, 37(4), 723-748. https://doi.org/10.1080/03066150.2010.512456

Gillon, S. (2016). Flexible for whom? Flex crops, crises, fixes and the politics of exchanging use values in US corn production. Journal of Peasant Studies, 43(1), 117-139. https://doi.org/10.1080/03066150.2014.996555

Glover, D. (2010). The corporate shaping of GM crops as a technology for the poor. The Journal of Peasant Studies, 37(1), 67-90. https://doi.org/10.1080/03066150903498754

Gusterson, H. (2017). From Brexit to Trump: Anthropology and the rise of nationalist populism. American Ethnologist, 44(2), 209-214. https://doi.org/10.1111/amet.12469

Hendrickson, M. K. (2015). Resilience in a concentrated and consolidated food system. Journal of Environmental Studies and Sciences, 5(3), 418-431. https://doi.org/10.1007/s13412-015-0292-2

Hinrichs, C. C. (2003). The practice and politics of food system localization. Journal of Rural Studies, 19(1), 33-45. https://doi.org/10.1016/S0743-0167(02)00040-2

Hochschild, A. R. (2016). Strangers in their own land: Anger and mourning on the American Right. The New Press.

Holt Giménez, E., \& Shattuck, A. (2011). Food crises, food regimes and food movements: rumblings of reform or tides of transformation? The Journal of Peasant Studies, 38(1), 109-144. https://doi.org/10.1080/03066150.2010.538578

Howard, P. H. (2016). Concentration and power in the food system: Who controls what we eat? Bloomsbury Publishing.

Janssen, B. (2017). Making local food work: The challenges and opportunities of today's small farmers. University of Iowa Press.

Kenner, R. (2008). Food, Inc. (film). Magnolia Pictures.

Kloppenburg, J. R. (2004). First the seed: The political economy of plant biotechnology, 1492-2000 (2nd ed.). University of Wisconsin Press. 
Kruzic, A., Carter, A., \& Fidel, R. (2016). When a banana is much more than a banana. Retrieved April 7, 2021, from Food First Blog website: https://foodfirst.org/when-a-banana-is-much-more-than-a-banana/

Magdoff, F., Foster, J. B., \& Buttel, F. H. (2000). An overview. In F. Magdoff, J. B. Foster, \& F. H. Buttel (Eds.), Hungry for profit: The agribusiness threat to farmers, food, and the environment (pp. 7-21). Monthly Review.

Malthus, T. R. (1798). An essay on the principle of population as it affects the future improvement of society with remarks on the speculations of Mr. Godwin, M. Condorcet, and Other Writers. London: J. Johnson.

McMichael, P. (2001). The impact of globalisation, free trade and technology on food and nutrition in the new millennium. The Proceedings of the Nutrition Society, 60, 215-220. https://doi.org/https://doi.org/10.1079/PNS200088

McMichael, P. (2009). A food regime genealogy. Journal of Peasant Studies, 36(1), $139-169$. https://doi.org/10.1080/03066150902820354

McMichael, P. (2010). Agrofuels in the food regime. Journal of Peasant Studies, 37(4), 609-629. https://doi.org/10.1039/c2ay25041a

Moragues-Faus, A., \& Marsden, T. (2017). The political ecology of food: Carving 'spaces of possibility' in a new research agenda. Journal of Rural Studies, 55, 275-288. https://doi.org/10.1016/j.jrurstud.2017.08.016

Mumm, R. H., Goldsmith, P. D., Rausch, K. D., \& Stein, H. H. (2014). Land usage attributed to corn ethanol production in the United States: Sensitivity to technological advances in corn grain yield, ethanol conversion, and co-product utilization. Biotechnology for Biofuels, 7(1), 1-17. https://doi.org/10.1186/1754-6834-7-61

Mutel, C. F. (2008). The emerald horizon: The history of nature in Iowa. University of Iowa Press.

OUP Blog. (2007). Oxford word of the year 2007: Locavore. Retrieved April 14, 2020, from https://blog.oup.com/2007/11/locavore/

Patel, R. (2007). Stuffed and starved: markets, power and the hidden battle for the world food system. Portobello Books.

Paxson, H. (2013). The life of cheese: Crafting food and value in America. Berkeley: University of California Press.

Perkins, J. H. (1990). The Rockefeller Foundation and the Green Revolution, 1941-1956. Agriculture and Human Values, 7(3-4), 6-18. https://doi.org/10.1126/science.35.893.213

Pfeffer, M. J. (1983). Social origins of three systems of farm production in the United States. Rural Sociology, 48(4), 540-562.

Pollan, M. (2006). The omnivore's dilemma: A natural history of four meals. Penguin.

Ponisio, L. C., M'Gonigle, L. K., Mace, K. C., Palomino, J., de Valpine, P., \& Kremen, C. (2014). Diversification practices reduce organic to conventional yield gap. Proceedings of the Royal Society Biological Sciences, 282(1799), 20141396. https://doi.org/10.1098/rspb.2014.1396

Rissing, A. (2016). Alternative economic strategies and the technology treadmill: Beginning vegetable farmers in Iowa. Economic Anthropology, 3(2), 304-314. https://doi.org/10.1002/sea2.12061

Rissing, A. (2019). Fences: Technologies, boundaries, and making change. Journal for the Anthropology of North America, 22(2), 66-68. https://doi.org/10.1002/nad.12106

Ritchie, M. (1993). Breaking the deadlock: The United States and agricultural policy in the Uruguay Round. draft.

Robbins, P. (2004). Political ecology: A critical introduction. Blackwell.

Schumacher, E. F. (1973). Small is beautiful: A study of economics as if people mattered. Harper Collins.

Scott, J. C. (1998). Seeing like a state: How certain schemes to improve the human condition have failed. Yale University Press. 
Sen, A. (1977). Starvation and exchange entitlements: a general approach and its application to the great Bengal famine. Cambridge Journal of Economics, $1(1), \quad 33-59$. https://doi.org/10.1093/oxfordjournals.cje.a035349

Seufert, V., Ramankutty, N., \& Foley, J. A. (2012). Comparing the yields of organic and conventional agriculture. Nature, 485(7397), 229-232. https://doi.org/10.1038/nature11069

Stone, G. D. (2010). The anthropology of genetically modified crops. Annual Review of Anthropology, 39(1), 381-400. https://doi.org/10.1146/annurev.anthro.012809.105058

Tregear, A. (2011). Progressing knowledge in alternative and local food networks: Critical reflections and a research agenda. Journal of Rural Studies, 27(4), 419-430. https://doi.org/10.1016/j.jrurstud.2011.06.003

USDA NASS. (2017). Iowa Ag News - 2016 Crop Production. Retrieved from https://www.nass.usda.gov/Statistics_by_State/Iowa/Publications/Crop_Report/2017/IA_Crop_Produc tion_Annual_01_17.pdf

USDA NASS. (2020). Iowa's rank in United States agriculture. Retrieved from https://www.nass.usda.gov/Statistics_by_State/Iowa/Publications/Rankings/IA-2020-Rankings.pdf

Vanclay, F., \& Enticott, G. (2011). The role and functioning of cultural scripts in farming and agriculture. Sociologia Ruralis, 51(3), 256-271. https://doi.org/10.1111/j.1467-9523.2011.00537.x

Vélez-Ibáñez, C. G. (2010). An impossible living in a transborder world: Culture, confianza, and economy of Mexica-Origin populations. University of Arizona Press.

Vélez-Ibáñez, C., \& Sampaio, A. (2002). Introduction: Processes, new prospects, and approaches. In Transnational Latina/o communities: politics, processes, and cultures (pp. 1-37). Rowman \& Littlefield.

von Tscharner Fleming, S. (2012). Introduction: Shovel sharpened, shovel ready. In Z. I. Bradbury, S. von Tscharner Fleming, \& P. Manalo (Eds.), Greenhorns: 50 dispatches from the new farmers' movement (pp. 8-11). Storey Publishing.

Walton, J., \& Seddon, D. (1994). Free Markets and Food Riots: The Politics of Global Adjustment. Cambridge, MA: Blackwell Publishers.

Warman, A. (2003). Corn and capitalism: How a botanical bastard grew to global dominance. Translated by Nancy L. Westrate. University of North Carolina Press.

Watts, M.J. (2000). Political ecology. In E. Sheppard \& T. Barnes (Eds.), A companion to economic geography. Blackwell.

Weis, T. (2007). The global food economy: The battle for the future of farming. Zed.

Weiss, B. (2016). Real pigs: shifting values in the field of local pork. Duke University Press.

Wilbois, K. P., \& Schmidt, J. E. (2019). Reframing the debate surrounding the yield gap between organic and conventional farming. Agronomy, 9(2), 1-16. https://doi.org/10.3390/agronomy9020082

Winders, B. (2009a). The politics of food supply: U.S. agricultural policy in the world economy. Yale University Press.

Winders, B. (2009b). The vanishing free market: The formation and spread of the British and US food regimes. Journal of Agrarian Change, 9(3), 315-344. https://doi.org/10.1111/j.1471-0366.2009.00214.x 